\title{
Enrichment of Gluten-free Cakes with Grape Molasses and Bioactive Rich Ingredients
}

\author{
Hacer Levent ${ }^{1^{*}}$ \\ https://orcid.org/0000-0002-7321-5577
}

Abdulvahit Sayaslan ${ }^{2}$

https://orcid.org/0000-0001-7161-1552

\author{
Saliha Yeşil ${ }^{2}$ \\ https://orcid.org/0000-0003-1806-7097
}

${ }^{1}$ Karamanoğlu Mehmetbey University, Department of Nutrition and Dietetics, Karaman, Turkey; ${ }^{2}$ Karamanoğlu Mehmetbey University, Department of Food Engineering, Karaman, Turkey.

Editor-in-Chief: Alexandre Rasi Aoki

Associate Editor: Acácio Antonio Ferreira Zielinski

Received: 2021.01.19; Accepted: 2021.06.23.

*Correspondence: hacerlevent@hotmail.com; Tel.: +90-338-2262131(H.L.).

\section{HIGHLIGHTS}

- The use of grape molasses and other additives reduced the cake brightness.

- Enriched cake samples had higher ash and crude protein content than control samples.

- All additives increased the total phenolic content and antioxidant activity $(p<0.05)$ of cake samples.

- Pomegranate seed and flaxseed improved the $\mathrm{Ca}, \mathrm{P}$ and $\mathrm{K}$ contents of control cakes.

\begin{abstract}
In this study, the sugar used in the gluten-free cake was substituted with $75 \%$ grape molasses. In addition, the gluten-free flour mixture used in the cake formulation was prepared as a combination of rice flour $(75 \%)$, chickpea flour (15\%)and carrot flour (10\%). This mixture was replaced separately with $5 \%$ grape seed, pomegranate seed, flaxseed, poppy seed and turmeric to improve the nutritional composition of glutenfree cakes. Supplemented cakes contained higher ash, crude protein, total phenolic content and antioxidant activity values than gluten-free control sample. Cake samples containing pomegranate seed and flaxseed had higher contents of $\mathrm{Ca}, \mathrm{P}$ and $\mathrm{K}$ than control cakes. In addition, flaxseed and poppy seed containing cakes were found richer in terms of $\mathrm{Mn}$ and $\mathrm{Mg}$ than control. Utilization of grape molasses together with grape seed, pomegranate seed, flaxseed, poppy seed and turmeric in formulation caused a reduction in volume index of cake samples. The hardness values of the gluten-free cakes were generally higher than that of the control. Cakes containing flaxseed and poppy seed scored higher in sensory analysis than other substituted samples. Based on these results, the use of grape molasses with flaxseed and poppy seed can be recommended for the production of gluten-free cakes with acceptable sensory properties and high total phenolic content and antioxidant activity.
\end{abstract}

Keywords:gluten-free; molasses; grape; pomegranate; poppy; flaxseed. 


\section{INTRODUCTION}

Celiac disease (CD) is triggered by the ingestion of gluten in genetically sensitive individuals [1]. CD is characterized by damage of the small intestinal mucosa and results in malabsorption in the small intestine. The alcohol-soluble gliadin fraction of wheat gluten and similar proteins in other grains are responsible for environmental factors of spontaneous mucosal damage[2]. These prolamins are very important not only for $\mathrm{CD}$, but also for non-coeliac gluten sensitivity, gluten ataxia and dermatitis herpetiformis [3].

Celiac patients can have typical gastrointestinal symptoms such as diarrhea, bloating, flatulence, steatorrhea, weight loss, abdominal pain, as well as non-gastrointestinal abnormalities such as anemia, liver function tests, bone disease, and skin disturbances. In addition, many people with celiac disease may have no symptoms at all [4].

The global prevalence of CD is $1.4 \%$ according to serological test results, and $0.7 \%$ according to biopsy results [5]. The only effective treatment for individuals with these diseases is to completely remove gluten from their diet throughout their life [3]. But some common packaged gluten-free foods have more fat and carbohydrates and less protein, iron and folate compared to regular products [6]. Also, commercially available gluten-free products are poorer in unsaturated fatty acids compared to their gluten-containing counterparts [7]. For that reason, following a gluten-free diet by people with CD causes some macro and micro nutrient deficiencies, as well as to excess saturated fat and carbohydrate intakes [8]. Furthermore, the lack of product range, limited availability, insufficient knowledge of the gluten-free diet and high product price are some of the other problems faced by celiac patients [9]. As a result, most patients are at risk for nutritional deficiency problems such as osteoporosis, anemia and growth retardation [8].

Chickpea is an important legume product in human nutrition due to its carbohydrate, protein, dietary fiber, vitamin and mineral content.Chickpeas contain significant amounts of all essential amino acids except sulfur-containing amino acids, which can be supplemented by cereals [10-11]. Carrots are rich in carbohydrates and minerals $(\mathrm{Ca}, \mathrm{Fe}, \mathrm{P}$ and $\mathrm{Mg}$ ) and bioactive compounds such as carotenoids and dietary fibers. It is rich in natural antioxidants which have anticancer activity [12]. Molasses, one of Turkey's traditional products, is mainly produced from grape. Since it contains organic acids, mineral substances and partially vitamins, the importance of molasses in nutrition is much more than granulated sugar [13-14]. Iron in grape molasses can be absorbed easily and 35\% of the daily iron need can be met by molasses that can be taken daily [15]. Grape seed, one of the waste materials of the wine industry, is valuable components due to its dietary fiber $(40 \%)$, protein $(11 \%)$, oil $(16 \%)$, complex phenols $(7 \%)$ including tannins and mineral salts contents[16]. The seeds are also rich source of monomeric phenolic compounds such as procyanidins and catechins which have antiviral and antimutagenic effects [16-17]. Flaxseed is a functional food ingredient with many health benefits. It contains $\alpha$-linolenic acid (ALA), dietary fiber and lignans, and these functional ingredients reduce the risks of cardiovascular diseases and hormone-dependent cancer types [18-19].

Pomegranate seeds, a by-product of the industrial processing of pomegranate, contain valuable oils with nutritional and medicinal properties [20]. Poppy seeds are an important industrial product grown for pharmaceutical and food applications since ancient times.Poppy seeds have a $45-50 \%$ oil content and seed oils have a desirable fatty acid composition with $73 \%$ linoleic, $13 \%$ oleic and $10 \%$ palmitic acid as the main fatty acids.In addition, poppy seeds contain carbohydrates, protein and bioactive compounds such as phenolics [21-22]. Turmeric is widely used in India, China, and South East Asia as a spice, coloring agent and food preservative.Curcumin is the main bioactive component of turmeric and it has been shown to have a wide range of biological activities such as antiinflammatory, antioxidant, anticarcinogenic, antimutagenic, antifertility, antidiabetic, hypotensive and hypocholesteremic effects [23].

Cake is a popular product that is consumed by people of all ages due to its unique taste, soft texture, ease of consumption and wide variety. It is a cereal product with a high production amount after bread and biscuit [24]. In this study, the gluten-free cake mixture was reformulated with rice flour, chickpea flour and carrots. Studies on the use of grape molasses in gluten-free cakes and enrichment with bioactive rich ingredients are very few. Therefore, the aim of this study is to improve the gluten-free cake formulation with grape molasses and bioactive rich substances and to evaluate the physical, chemical and sensory quality of the cakes. 


\section{MATERIAL AND METHODS}

\section{Materials}

Rice flour, carrot, chickpea, sugar, shortening, grape molasses, egg, milk powder, salt, baking powder, ethyl vanillin, grape seed, flaxseed, poppy seed and turmeric were obtained from local markets in Karaman, Turkey. Grape seed, flaxseed, poppy seed, and pomegranate seed were ground in a coffee grinder $(<500$ $\mu \mathrm{m})$ prior to cake production. Fresh carrot was dried in the oven (KD-200, Ankara, Turkey) below $10 \%$ moisture content. Then dried carrot was ground in a hammer mill (POLYMIX, Kinematica AG, Switzerland) and sieved to obtain final powder size $<350 \mu \mathrm{m}$. Chickpeas were ground into flour with the same laboratory hammer mill. Guar gum was obtained from Tunçkaya Inc., Istanbul, Turkey. DATEM (diacetyl tartaric acid esters of monoglycerides) was kindly provided by Aspek Kimya, Istanbul, Turkey.

\section{Preparation of cake samples}

In the study, two control cake samples were produced. First control cake is prepared with wheat flour, and second control cake is prepared with gluten-free flour mix instead of wheat flour. Gluten-free flour mixture consists of rice flour (75\%), chickpea flour (15\%) and carrot flour (10\%). For prepation of supplemented cake samples, gluten-free flour mixture was replaced by $5 \%$ with grape seed, pomegranate seed, flaxseed, poppy seed and turmeric, separately. Also, the sugar in the gluten-free cake samples was replaced by $75 \%$ grape molasses. The details of cake formulations are given in Table 1. A single application ratio was used to compare the effects of additives and this ratio was determined by preliminary trials. Firstly, shortening and sugar are whipped in the mixer (Kitchen Aid, Artisan, USA) until it turns into white cream. After the egg is added, mixing continues for 5 more min. The remaining ingredients are then added and mixed for 1 min to obtain a homogeneous cake batter. Baking of the cakes was carried out in the oven (Bosch HGD52D12T, Istanbul, Turkey) at $170{ }^{\circ} \mathrm{C}$ for $30 \mathrm{~min}$. After baking, the cakes were demoulded and allowed to cool for 30 min. Then, the cake samples were stored in sealed bags until analysis.

Table 1. Experimental design for gluten-free cake production

\begin{tabular}{|c|c|c|c|c|c|c|c|}
\hline Ingredients (g) & Control (WF) & Control (GF) & SC1 & $\mathrm{Sc2}$ & Sc3 & $\mathrm{SC} 4$ & SC5 \\
\hline Wheat flour & 100 & - & - & - & - & - & - \\
\hline $\begin{array}{l}\text { Gluten-free flour mix }(75 \% \\
\text { RF:15\%CHF:10\%CF) }\end{array}$ & - & 100 & 95 & 95 & 95 & 95 & 95 \\
\hline Shortening & 150 & 150 & 150 & 150 & 150 & 150 & 150 \\
\hline Fine granulating sucrose & 150 & 150 & 37.5 & 37.5 & 37.5 & 37.5 & 37.5 \\
\hline Grape molasses & - & - & 112.5 & 112.5 & 112.5 & 112.5 & 112.5 \\
\hline Skimmed milk powder & 10 & 10 & 10 & 10 & 10 & 10 & 10 \\
\hline Whole egg & 150 & 150 & 150 & 150 & 150 & 150 & 150 \\
\hline Salt & 1 & 1 & 1 & 1 & 1 & 1 & 1 \\
\hline Baking powder & 9 & 9 & 9 & 9 & 9 & 9 & 9 \\
\hline DATEM & 1 & 1 & 1 & 1 & 1 & 1 & 1 \\
\hline Ethyl vanillin & 0.2 & 0.2 & 0.2 & 0.2 & 0.2 & 0.2 & 0.2 \\
\hline Grape seed & - & - & 5 & - & - & - & - \\
\hline Pomegranate seed & - & - & - & 5 & - & - & - \\
\hline Flaxseed & - & - & - & & 5 & - & - \\
\hline Poppy seed & - & - & - & - & - & 5 & - \\
\hline Turmeric & - & - & - & - & - & - & 5 \\
\hline
\end{tabular}

WF: Wheat flour; GF: Gluten-free;RF:Rice flour; CHF:Chickpea flour; CF:Carrot flour; SC:Supplemented cake; DATEM: Diacetyl tartaric acid esters of monoglycerides

\section{Cake batter and cake analyses}

Specific gravity of cake batters was measured by dividing the weight of the batter in a container of known volume by the weight of the distilled water in the same container. Cake batter mixed with distilled water at a ratio of 1 (batter): 10 (distilled water) and the $\mathrm{pH}$ of the mixture was measured by a pH meter (WTW pH 315, Weilheim, Germany) calibrated with buffer solutions of $\mathrm{pH} 4.0$ and 10.0. 


\section{Cake properties}

The volume, symmetry index and uniformity index determination tests were performed using AACC Method (10-91). The crust and crumb color of the cake samples were measured with Hunter Lab Color Quest II Minolta CR-400 (Minolta Camera, Co., Ltd., Osaka Japan). L*(brightness), a*(red-green) and b*(yellowblue) values were determined on the day of baking. The hardness of the cake slices was measured using a TA-XT2 Texture Analyzer (Texture Tech. Corp., England, U.K.) with an aluminum P36 / R cylindrical probe at room temperature. The instrument setting were as follows: Trigger force $0.049 \mathrm{~N}$, distance $5 \mathrm{~mm}$, the pretest, test, and posttest speeds were $1.0 \mathrm{~mm} / \mathrm{s}, 2.0 \mathrm{~mm} / \mathrm{s}$ and $10 \mathrm{~mm} / \mathrm{s}$, respectively.

\section{Chemical analysis}

Raw materials and cake samples were analyzed for moisture, ash, crude protein and crude fat contents using standard AACC procedures [25]. Ca, P, K, Fe, Mn, Mg, Zn and Cu elements were determined by ICPOES (inductively coupled plasma optical emission spectrometry) (Agilent 720, Agilent Technologies, Santa Clara, CA, USA) [26].

Total phenolic content (TPC) was determined with the Folin-Ciocalteu reagent using gallic acid as standard [27]. The powdered cake samples $(1 \mathrm{~g})$ were extracted for $2 \mathrm{~h}$ with $10 \mathrm{~mL}$ of $80 \%$ aqueous methanol $(1 / 10 ; w / v)$ at room temperature. Then samples were centrifuged at $2600 \mathrm{~g}$ for $15 \mathrm{~min}$. For total phenol assay, $0.1 \mathrm{~mL}$ of supernatant, $0.9 \mathrm{~mL}$ distilled water, $1 \mathrm{~mL}$ Folin-ciocalteu reagent $(90 \%, \mathrm{v} / \mathrm{v})$ and $2 \mathrm{~mL}$ sodium carbonate solution $(10 \%, \mathrm{w} / \mathrm{v})$ were mixed. The mixture was kept in the dark for $60 \mathrm{~min}$ at room temperature. Using a spectrophotometer (Shimadzu UV-1800, Shimadzu Inc., Kyoto, Japan) at $765 \mathrm{~nm}$, absorbance of the mixture was measured and total phenolic content was expresses as gallic acid equivalent (GAE).

DPPH scavenging activity (\%), was measured following a previous method [27] with small modification. For the preparation of the sample extracts, the method of total phenolic content analysis was used. To prepare the DPPH (2,2-diphenyl-I-picrylhydrazyl) radical solution, $10 \mathrm{mg}$ DPPH was dissolved in $25 \mathrm{ml} 80 \%$ methanol. Exactly, $100 \mu \mathrm{L}$ of $80 \%$ methanol extract was mixed with $250 \mu \mathrm{L}$ of DPPH solution and $2 \mathrm{~mL}$ of $80 \%$ methanol. The mixture was shaken vigorously and kept for $20 \mathrm{~min}$ in the dark at room temperature. A mixture of $250 \mu \mathrm{L}$ of methanol DPPH solution and $2.1 \mathrm{~mL}$ of $80 \%$ methanol was used as blank. Using a spectrophotometer (Shimadzu UV-1800, Shimadzu Inc., Kyoto, Japan) at $517 \mathrm{~nm}$, the decrease in absorbance (\%) of the resulting solution was monitored for $20 \mathrm{~min}$.

Trolox equivalent antioxidant capacity (TEAC) was also measured against 2,2 azinobis-3ethylbenzothiazolin-6-sulfonic acid $\left(\mathrm{ABTS}^{+}\right)$radical using spectrophotometric assay [28]. For the assay, ABTS $^{+}$solution $(7 \mathrm{mM})$ containing $2.45 \mathrm{mM}$ potassium persulfate was prepared and the mixture was kept in the dark for $12-16 \mathrm{~h}$ at room temperature. To prepare the $\mathrm{ABTS}^{+}$working solution, the stock radical solution was diluted with PBS (Phosphate buffered saline) to an absorbance of $0.70 \pm 0.02$ at $734 \mathrm{~nm}$. Sample extract $(10,20$ and $30 \mu \mathrm{L})$ was reacted with $1 \mathrm{~mL}$ of $\mathrm{ABTS}^{+}$working solution. Absorbance inhibition percentages were calculated using absorbance values at the beginning and at the end of $6 \mathrm{~min}$. The same procedure was carried out for the standard Trolox concentrations $(5,10,15$ and $20 \mu \mathrm{M})$. The TEAC value was calculated using the curve slopes of the sample and the standard. The results are reported as $\mathrm{mM}$ Trolox $/ 100 \mathrm{~g}$.

\section{Sensory evaluation}

Sensory analyzes were performed by 26 healthy non-smoking panelists between the ages of $23-48$. To avoid any bias, the coded cake samples were presented to the panelists at room temperatures in a random order. Panelists were asked to clean their mouths with purified drinking water between tests to minimize any residual effect. The cake samples were evaluated in terms of appearance, texture, taste-odor, mouthfeel and overall acceptability using a scale 1-9 where (1) extreme dislike and (9)- extreme liked. All samples were compared with control.

\section{Statistical analysis}

All measurements were performed in triplicate. The data was processed using a statistical analyses software JMP 5.0.1 (SAS Institute Inc., Cary, NC, USA). Results were reported as the mean \pm standard deviation. Differences in samples were tested for statistical significance at the $p=0.05$ level. 


\section{RESULTS AND DISCUSSION}

Some properties of the batter and cake samples are presented in Table 2. Batter specific gravity and $\mathrm{pH}$ ranged from 0.86 to $0.92 \mathrm{~g} / \mathrm{cm}^{3}$ and 6.83 to 7.06 , respectively. Baking loss (\%) values of gluten-free cake samples ranged between 10.54 and 14.03. The highest volume index and symmetry index value was determined in the control sample (WF). Pomegranate seed, flaxseed, poppy seed and turmeric decreased to volume index from 139 to $122-112 \mathrm{~mm}$. Volume index is higly correlated with volume and in general the fortification caused a decrease in the volume index values in the cake samples.In this study, sugar was replaced by $75 \%$ grape molasses. In addition to the additives, the use of grape molasses in cake formulation was also effective in reducing the volume. Sugar content has been reported to correlate positively with volumetric expansion in gluten-free cakes using baking powders [29]. Similarly, [30] reported a decrease in volume of cakes with the replacement of pekmez with crystal sugar. Also, this reduction may be due to the presence of fibers in ingredients that may have collapsed the carbon dioxide gas bubbles during cooking and led to a reduction in volume [31]. [32] used flaxseed powder in muffin formulation (10-40\%) and reported that the cake volumes (cc) decreased from 150 to 145 with the use of raw flaxseed powder. [33] reported that the use of grape seed flour over $5 \%$ decreased the bread volume and increased bread hardness and porosity.

Table 2. Some properties of batters and cake samples

\begin{tabular}{lcccccc}
\hline & $\begin{array}{l}\text { Batter specific } \\
\text { gravity }\left(\mathbf{g} / \mathbf{c m}^{3}\right)\end{array}$ & $\begin{array}{l}\text { Batter } \\
\mathbf{p H}\end{array}$ & $\begin{array}{l}\text { Baking loss } \\
(\%)\end{array}$ & $\begin{array}{l}\text { Volume } \\
\text { Index }(\mathbf{m m})\end{array}$ & $\begin{array}{l}\text { Symmetry } \\
\text { index }(\mathbf{m m})\end{array}$ & $\begin{array}{l}\text { Uniformity } \\
\text { index }(\mathbf{m m})\end{array}$ \\
\hline Control (WF) & $0.86 \pm 0.04^{\mathrm{a}}$ & $6.89 \pm 0.07^{\mathrm{ab}}$ & $10.54 \pm 0.74^{\mathrm{a}}$ & $164 \pm 1.41^{\mathrm{a}}$ & $13.0 \pm 1.27^{\mathrm{a}}$ & $-5.0 \pm 0.71^{\mathrm{c}}$ \\
Control (GF) & $0.92 \pm 0.01^{\mathrm{a}}$ & $7.06 \pm 0.03^{\mathrm{a}}$ & $12.67 \pm 1.40^{\mathrm{a}}$ & $139 \pm 4.24^{\mathrm{b}}$ & $8.0 \pm 1.13^{\mathrm{bc}}$ & $0.0 \pm 0.14^{\mathrm{ab}}$ \\
GM+GS & $0.90 \pm 0.07^{\mathrm{a}}$ & $6.93 \pm 0.04^{\mathrm{ab}}$ & $13.02 \pm 0.51^{\mathrm{a}}$ & $136 \pm 0.71^{\mathrm{b}}$ & $5.0 \pm 0.85^{\mathrm{c}}$ & $1.0 \pm 0.14^{\mathrm{a}}$ \\
GM+ PMS & $0.92 \pm 0.07^{\mathrm{a}}$ & $6.83 \pm 0.03^{\mathrm{b}}$ & $14.03 \pm 1.77^{\mathrm{a}}$ & $121 \pm 2.83^{\mathrm{cd}}$ & $4.6 \pm 0.31^{\mathrm{c}}$ & $1.0 \pm 0.57^{\mathrm{a}}$ \\
GM+FS & $0.91 \pm 0.01^{\mathrm{a}}$ & $6.90 \pm 0.01^{\mathrm{ab}}$ & $11.72 \pm 0.88^{\mathrm{a}}$ & $118 \pm 2.12^{\mathrm{cd}}$ & $11.0 \pm 0.58^{\mathrm{ab}}$ & $-5.0 \pm 0.28^{\mathrm{c}}$ \\
GM+PS & $0.90 \pm 0.01^{\mathrm{a}}$ & $6.88 \pm 0.06^{\mathrm{ab}}$ & $12.10 \pm 0.30^{\mathrm{a}}$ & $112 \pm 0.71^{\mathrm{d}}$ & $8.0 \pm 1.02^{\mathrm{bc}}$ & $0.0 \pm 0.14^{\mathrm{ab}}$ \\
GM+T & $0.92 \pm 0.03^{\mathrm{a}}$ & $6.90 \pm 0.07^{\mathrm{ab}}$ & $13.11 \pm 0.72^{\mathrm{a}}$ & $122 \pm 2.26^{\mathrm{c}}$ & $7.2 \pm 0.64^{\mathrm{c}}$ & $-1.0 \pm 0.35^{\mathrm{b}}$ \\
\hline
\end{tabular}

Mean values represented by different letters are statistically different from each other $(p<0.05)$. Values are the average of triplicate measurements on the duplicate samples. WF: Wheat flour. GF:Gluten-free; GM: Grape molasses; GS: Grape seed; PMS: Pomegranate seed; FS:Flaxseed; PS:Poppy seed; T:Turmeric

High symmetry index value indicates that cakes rise mainly in the middle part [34]. Grape seed, pomegranate seed, and turmeric reduced the symmetry index value compared to the gluten-free control sample, but this decrease was insignificant.Except for the flaxseed enriched samples, the symmetry index values of the gluten-free cakes were not different from the gluten-free control samples. The uniformity index is desirable to be close to zero for good quality cakes [35]. It was found that the unuformity index values of the cakes were in the range of $-5.0-1.0 \mathrm{~mm}$. The uniformity index was found to be zero in cakes enriched with poppy seed and gluten-free control sample.

Table 3 shows the crust and crumb color values of cake samples. The color of a baked product comes from the color of ingredients and their interactions [36].In addition, the Maillard reaction between sugar and amino acids and the caramelization process of sugars are responsible for the crust color of the cake [37]. The crust $L$ * value of the gluten-free cake samples varied between 32.03 and 43.43 , and the crust $L$ * values of the enriched samples were found to be lower than the gluten-free control sample.The highest crust $L$ * and crust $b$ * values were determined in grape seed enriched samples after the gluten-free control sample. It was also observed that the cake samples prepared with pomegranate seed and turmeric had the highest crust a * value. The differences between the crust colors in the cake samples may have resulted from the natural color characteristics of the raw materials, different protein amounts and amino acid compositions. When the crumb color values of the gluten-free cakes were evaluated, it was observed that the lowest $L^{*}$ value (44.43) was in the samples prepared with turmeric. All supplemantations reduced the crumb $L^{*}$ and increased the crumb $a^{*}$ and $b^{*}$ values compared to the gluten-free control samples. [38] observed similar results reporting lower $L^{*}$ and higher $a^{*}$ for uncooked and cooked noodle samples prepared with grape, pomegranate and rosehip seed flours than control samples. [39] used turmeric in bread formulation (2-8\%) and reported that crumb color and b values increased with the use of turmeric. In a study by [40], as the grape seed flour ratio increased, the colour of the cookies became darker. Similarly, breads containing flaxseed flour revealed a darker crumb than the control bread, which was attributed to the original dark color of flaxseed flour [41]. 
Table 3. Color analysis results of gluten-free cake samples

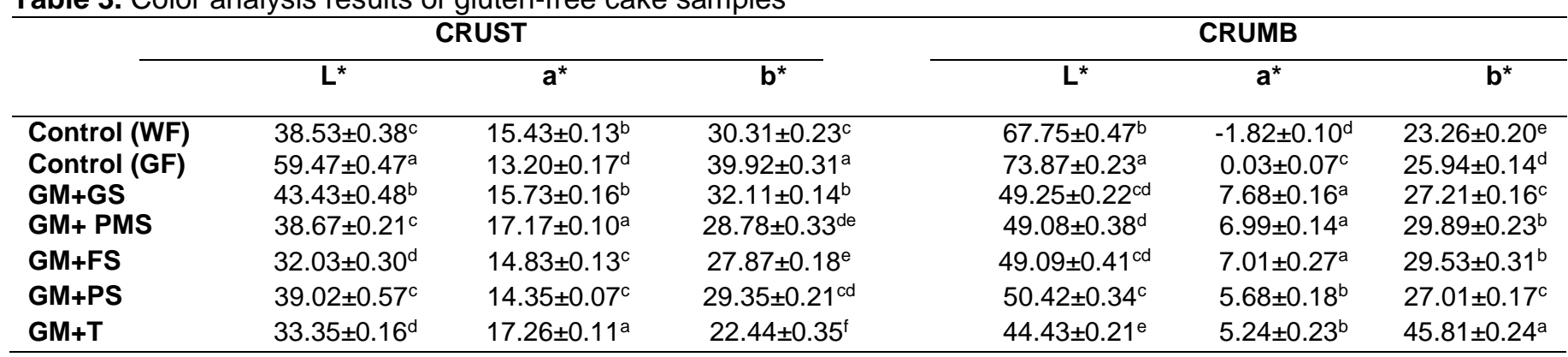

Mean values represented by different letters are statistically different from each other $(p<0.05)$. Values are the average of triplicate measurements on the duplicate samples. WF: Wheat flour. GF:Gluten-free; GM: Grape molasses; GS: Grape seed; PMS: Pomegranate seed; FS:Flaxseed; PS:Poppy seed; T:Turmeric

The results of chemical analysis of cake samples are presented in Table 4. Moisture and ash content of gluten-free cake samples ranged from 24.84 to $28.72 \%$ and 1.66 to $2.15 \%$, respectively. All supplementations significantly increased ash and crude protein content compared to gluten-free control cake samples. The crude fat contents of the cakes prepared with flaxseed (24.71\%) and poppy seed $(24.84 \%)$ were found to be higher than those prepared with grape seed $(22.90 \%)$ and turmeric $(23.04 \%)$. The high crude fat and protein content of flaxseed and poppy seed were noteworthy as raw materials, and these results may have an impact on the fat and protein content of final product (data not shown). Flaxseed has been reported to have a high content of fat $(40 \%)$, protein $(20 \%)$ and dietary fiber (30\%) [42]. [43] reported that poppy seed have high protein, fat and $\mathrm{Ca}, \mathrm{P}$ and $\mathrm{K}$ contents. [32] reported that addition of raw and roasted flaxseed powder (10$40 \%$ ) into the muffin increased the ash, fat and protein content of the samples.

Table 4. Chemical analysis results of gluten-free cake samples

\begin{tabular}{|c|c|c|c|c|c|c|c|}
\hline & $\begin{array}{c}\text { Moisture } \\
(\%)\end{array}$ & $\begin{array}{l}\text { Ash } \\
(\%)^{*}\end{array}$ & $\begin{array}{c}\text { Crude protein } \\
(\%)^{\star}\end{array}$ & $\begin{array}{c}\text { Crude fat } \\
(\%)^{\star}\end{array}$ & $\begin{array}{c}\text { TFM } \\
(\mathrm{mg} \mathrm{GAE} / \mathbf{k g})^{\star}\end{array}$ & $\begin{array}{c}\text { DPPH } \\
(\%)^{\star}\end{array}$ & $\begin{array}{c}\text { TEAC }_{\text {ABTS }} \\
(\mathrm{mM} / \mathbf{1 0 0 g})^{*}\end{array}$ \\
\hline Control (WF) & $21.22 \pm 0.59^{c}$ & $1.81 \pm 0.01^{b}$ & $7.96 \pm 0.08^{d}$ & $21.84 \pm 0.48^{c}$ & $158.15 \pm 4.45^{d}$ & $15.45 \pm 0.59^{d}$ & $42.50 \pm 9.76^{d}$ \\
\hline Control (GF) & $25.20 \pm 0.85^{b}$ & $1.66 \pm 0.03^{b}$ & $8.31 \pm 0.06^{d}$ & $22.12 \pm 0.31^{b c}$ & $167.82 \pm 10.32^{d}$ & $16.20 \pm 0.25^{d}$ & $57.12 \pm 10.07^{d}$ \\
\hline GM+GS & $26.12 \pm 0.31^{b}$ & $2.11 \pm 0.06^{a}$ & $8.81 \pm 0.11^{\mathrm{c}}$ & $22.90 \pm 0.55^{b c}$ & $1058.21 \pm 7.34^{\mathrm{b}}$ & $40.32 \pm 0.92^{b}$ & $732.00 \pm 8.06^{b}$ \\
\hline GM & $26.30 \pm 0.28^{b}$ & $2.14 \pm 0.01^{a}$ & $2 \pm 0.07^{\mathrm{abc}}$ & $42 \pm 0.17^{a b}$ & $843.85 \pm 13.22^{c}$ & $35.68 \pm$ & $1 \pm 9.52^{c}$ \\
\hline $\mathrm{GM}+\mathrm{FS}$ & $25.44 \pm 0.45^{\mathrm{b}}$ & $2.07 \pm 0.00^{\mathrm{a}}$ & $9.28 \pm 0.10^{\mathrm{ab}}$ & $24.71 \pm 0.3^{a}$ & $1074.62 \pm 6.11^{b}$ & $40.85 \pm 1.23^{b}$ & $726.10 \pm 10.60^{b}$ \\
\hline GM+PS & $28.72 \pm 0.68^{a}$ & $2.08 \pm 0.10^{a}$ & $9.55 \pm 0.08^{a}$ & $24.84 \pm 0.48^{a}$ & $866.92 \pm 7.95^{\mathrm{c}}$ & $37.90 \pm 0.64^{\mathrm{bc}}$ & $640.28 \pm 13.40^{\circ}$ \\
\hline GM+T & $24.84 \pm 0.37^{b}$ & $2.15 \pm 0.11^{\mathrm{a}}$ & $8.95 \pm 0.20^{b c}$ & $23.04 \pm 0.21^{b c}$ & $1120.56 \pm 9.56^{a}$ & $45.56 \pm 0.41^{a}$ & $993.42 \pm 9.73^{a}$ \\
\hline
\end{tabular}

${ }^{*}$ Results are on dry weight basis; Mean values represented by different letters are statistically different from each other $(p<0.05)$. TFM: Total phenolic content; GAE: Gallic acit equivalents;TEAC:Trolox equivalent antioxidant capacity. Values are the average of triplicate measurements on the duplicate samples. WF: Wheat flour. GF:Gluten-free; GM: Grape molasses; GS: Grape seed; PMS: Pomegranate seed; FS:Flaxseed; PS:Poppy seed; T:Turmeric

Total phenolic content of gluten-free cake samples changed between 167.82 and $1120.56 \mathrm{mg} \mathrm{GAE} / \mathrm{kg}$. All supplementations increased the total phenolic content significanlty $(p<0.05)$ compared to control samples, the highest value was obtained with turmeric. As in the total phenolic analysis, grape seed, pomegranate seed, flaxseed, poppy seed and turmeric significantly increased the antioxidant activity of the control cake samples. It is reported that grape and grape products are rich in phenolic compounds, particularly flovonoids which have anticarcinogenic, antimicrobial, anti-inflammatory, antiatherogenic and antioxidant activities [44]. Cake samples containing turmeric revealed the highest antioxidant activity value (DPPH, $45.56 \%$ and TEAC $_{\text {ABTs }}, 993.42 \mathrm{mM} / 100 \mathrm{~g}$ ) among the cake samples.

In another study by [45], it was reported that the use of turmeric and mahaleb (5 and $7.5 \%$ ) increased the total phenolic and antioxidant activity values of cracker samples. [40] reported that the use of grape seed flour in the formulation (5, 7.5 , and $10 \%)$ increased the total phenolic content and antioxidant activity values of the control cookie samples.

Mineral contents of cake samples are reported in Table 5. The Ca, $\mathrm{P}$ and $\mathrm{K}$ contents of the gluten-free control sample were higher than the control sample prepared with wheat flour. The use of chickpea flour and carrot flour in gluten-free control sample formulation improved the overall mineral matter compared to the control sample prepared with wheat flour. $\mathrm{Ca}, \mathrm{P}, \mathrm{K}, \mathrm{Fe}, \mathrm{Mn}, \mathrm{Mg}, \mathrm{Zn}$ and $\mathrm{Cu}$ contents $(\mathrm{mg} / 100 \mathrm{~g})$ of glutenfree control samples increased from 57.86 to $60.35-92.30(\mathrm{Ca}), 275.10$ to 285.67-329.67 (P), 155.42 to $168.42-202.70(\mathrm{~K}), 0.92$ to $0.98-1.36(\mathrm{Fe}), 0.87$ to $0.89-1.28(\mathrm{Mn}), 15.63$ to $21.68-42.63(\mathrm{Mg}), 0.64$ to $0.77-$ $0.96(\mathrm{Zn})$ and 0.12 to $0.17-0.30(\mathrm{Cu})$, respectively. An increase was determined in all mineral contents, but 
no significant difference was determined between $\mathrm{Fe}, \mathrm{Zn}$ and $\mathrm{Cu}$ contents of cake samples. [46] used grape seed, blueberry and poppy seed in cookie formulation (5\%) and reported that the all fortification agents increased $\mathrm{Mg}$ and $\mathrm{Ca}$ contents significantly $(\mathrm{p}<0.05)$. [47] reported that poppy seed is rich in $\mathrm{Ca}, \mathrm{P}, \mathrm{K}, \mathrm{Mg}$ and Mn contents.

The lowest hardness value of gluten-free cakes was determined in the control sample. The use of grape seed, pomegranate seed, flaxseed, poppy seed and turmeric in the gluten-free cake formulation caused an increase in the hardness values, while no significant difference was found between the hardness values of the enriched samples (Figure 1). [39] reported an increase in hardness with the addition of turmeric (2-8\%) to bread formulation. Similarly, [48] reported that the crumb hardness of white bread increased with the use of ground flaxseed (15\%) in the formulation. The increase in crumb hardness is attributed to the lower loaf volume and denser texture. Similarly, [33] reported increased bread hardness with the use of grape seed flour over $5 \%$.

The use of grape seed, pomegranate seed, poppy seed, flaxseed, and turmeric in addition to grape molasses in cake samples resulted in lower appearance, texture, mouthfeel and overall acceptability scores compared to the gluten-free control sample (Figure 2). Cake samples prepared with poppy seed and grape seed scored equivalent to the gluten-free control sample in terms of taste-odor. In the cake samples, grape seed, pomegranate seed and turmeric decreased the mouthfeel scores more than the flaxseed and poppy seed compared to the control sample. Cakes containing poppy seed and flaxseed received the highest overall acceptability scores after the control sample. [49] used ground flaxseed flour in bread and reported that bread sample prepared with $15 \%$ flaxseed flour was the most similar to control. In addition, flaxseed breads at other ratios were also found acceptable. Similar results regarding that flaxseed did not have a negative effect on sensory properties were reported by [41]. [33] used grape seed flour in the bread formulation (0-10\%) and reported that breads prepared with $5 \%$ grape seed flour had acceptable physical and sensory properties.

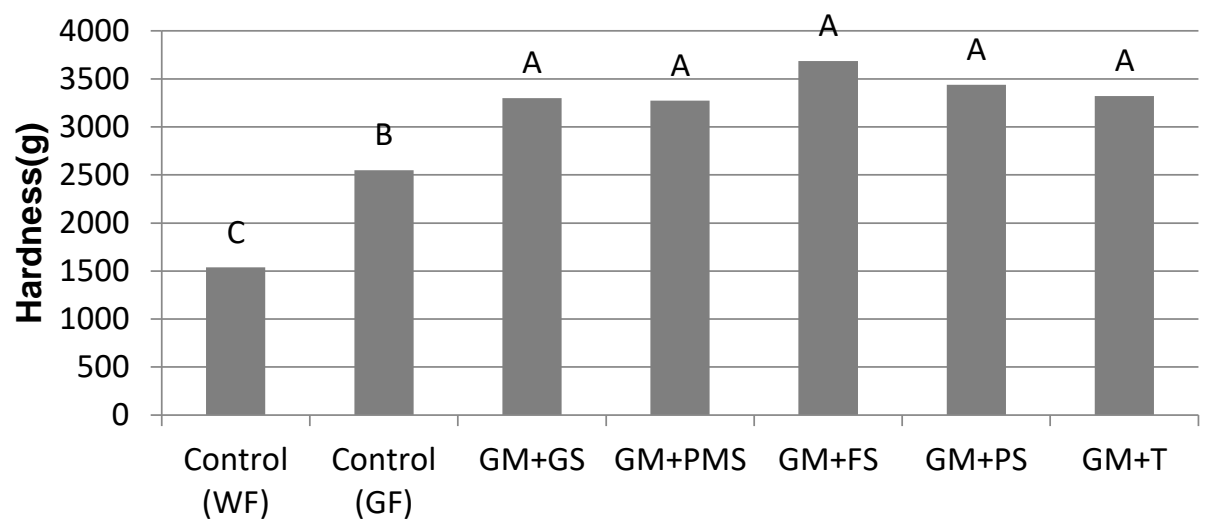

Figure 1. Hardness values of gluten-free cake samples (WF: Wheat flour. GF:Gluten-free; GM: Grape molasses; GS: Grape seed; PMS: Pomegranate seed; FS:Flaxseed; PS:Poppy seed; T:Turmeric)

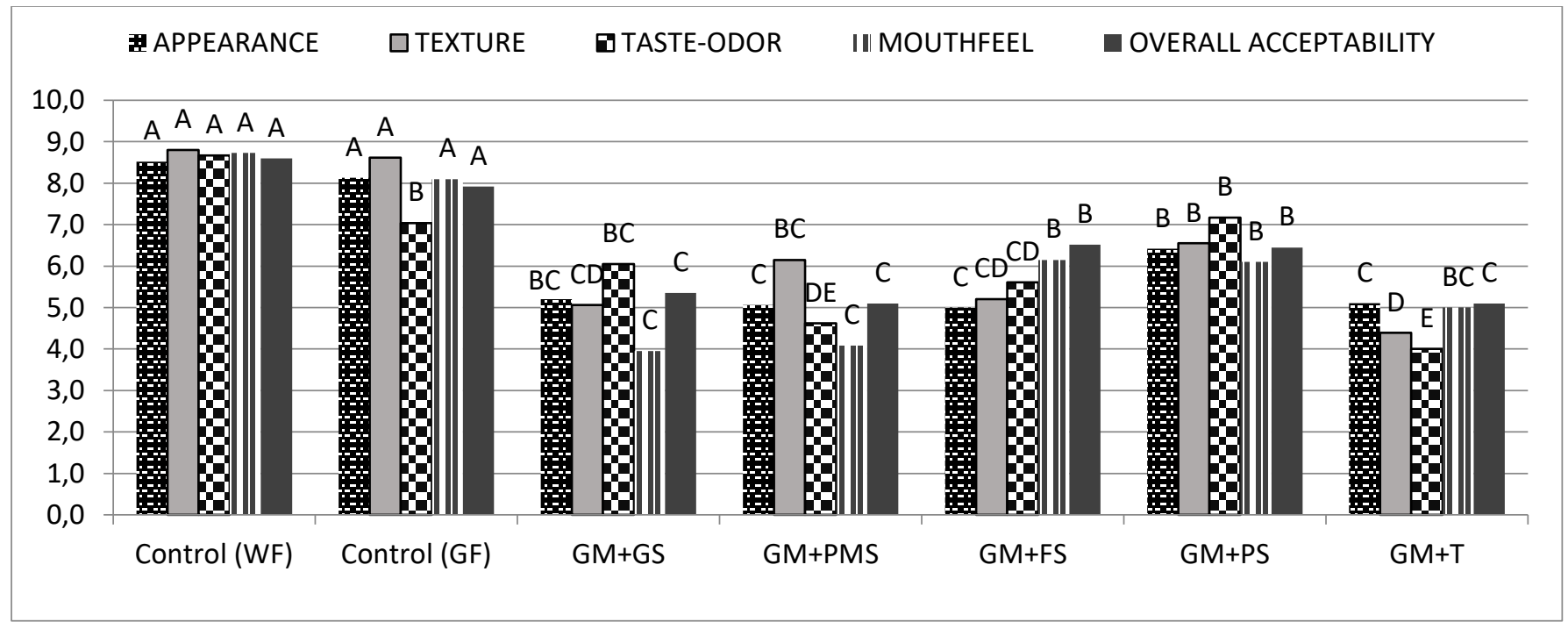

Figure 2. Sensory analysis results of gluten-free cake samples (WF: Wheat flour. GF:Gluten-free; GM:Grape molasses; GS:Grape seed; PMS:Pomegranate seed; FS:Flaxseed; PS:Poppy seed; T:Turmeric) 
Table 5. Mineral contents of gluten-free cake samples $(\mathrm{mg} / 100 \mathrm{~g})^{*}$

\begin{tabular}{|c|c|c|c|c|c|c|c|c|}
\hline & $\mathrm{Ca}$ & $\mathbf{P}$ & K & $\mathrm{Fe}$ & Mn & Mg & Zn & $\mathrm{Cu}$ \\
\hline Control (WF) & $34.75 \pm 0.72^{\mathrm{d}}$ & $241.00 \pm 6.36^{d}$ & $118.20 \pm 4.48^{\mathrm{c}}$ & $0.47 \pm 0.16^{\mathrm{a}}$ & $0.32 \pm 0.10^{\mathrm{b}}$ & $\begin{array}{l}8.56 \pm 1.64^{d} \\
15.63 \pm 2.87^{c}\end{array}$ & $0.57 \pm 0.08^{\mathrm{a}}$ & $0.10 \pm 0.08^{a}$ \\
\hline $\begin{array}{l}\text { Control (GF) } \\
\text { GM+GS }\end{array}$ & $\begin{array}{l}57.86 \pm 1.40^{c} \\
92.30 \pm 3.21^{a}\end{array}$ & $\begin{array}{l}275.10 \pm 7.17^{\mathrm{c}} \\
293.20 \pm 3.82^{\mathrm{bc}}\end{array}$ & $\begin{array}{l}155.42 \pm 7.24^{\mathrm{b}} \\
176.13 \pm 5.37^{\mathrm{ab}}\end{array}$ & $\begin{array}{l}0.92 \pm 0.24^{a} \\
0.98 \pm 0.25^{a}\end{array}$ & $\begin{array}{l}0.87 \pm 0.24^{\mathrm{ab}} \\
0.89 \pm 0.17^{\mathrm{ab}}\end{array}$ & $\begin{array}{l}\text { d } \\
21.68 \pm 2.57^{b} \\
c\end{array}$ & $\begin{array}{l}0.64 \pm 0.03^{a} \\
0.77 \pm 0.08^{a}\end{array}$ & $\begin{array}{l}0.12 \pm 0.14^{\mathrm{a}} \\
0.18 \pm 0.10^{\mathrm{a}}\end{array}$ \\
\hline GM+ PMS & $77.86 \pm 2.06^{b}$ & $310.63 \pm 7.40^{\mathrm{ab}}$ & $202.70 \pm 14.28^{a}$ & $1.07 \pm 0.16^{a}$ & $0.93 \pm 0.18^{\mathrm{ab}}$ & $24.50 \pm 3.90^{b}$ & $0.82 \pm 0.11^{a}$ & $0.30 \pm 0.13^{a}$ \\
\hline $\begin{array}{l}\text { GM+FS } \\
\text { GM+PS }\end{array}$ & $\begin{array}{l}79.96 \pm 4.47^{\mathrm{ab}} \\
91.28 \pm 3.05^{\mathrm{a}}\end{array}$ & $\begin{array}{l}321.85 \pm 10.25^{a} \\
329.67 \pm 7.17^{a}\end{array}$ & $\begin{array}{l}191.36 \pm 6.31^{\mathrm{a}} \\
183.09 \pm 7.76^{\mathrm{ab}}\end{array}$ & $\begin{array}{l}1.36 \pm 0.23^{a} \\
1.22 \pm 0.28^{a}\end{array}$ & $\begin{array}{l}1.09 \pm 0.20^{\mathrm{a}} \\
1.28 \pm 0.10^{\mathrm{a}}\end{array}$ & $\begin{array}{l}42.63 \pm 1.46^{a} \\
28.63 \pm 4.00^{a}\end{array}$ & $\begin{array}{l}0.96 \pm 0.13^{a} \\
0.93 \pm 0.17^{a}\end{array}$ & $\begin{array}{l}0.27 \pm 0.08^{a} \\
0.20 \pm 0.11^{a}\end{array}$ \\
\hline $\mathrm{GM}+\mathrm{T}$ & $60.35 \pm 5.26^{c}$ & $285.67 \pm 6.58^{\mathrm{bc}}$ & $168.42 \pm 12.02^{a b}$ & $1.31 \pm 0.31^{\mathrm{a}}$ & $0.94 \pm 0.14^{\mathrm{ab}}$ & $25.67 \pm 2.93^{b}$ & $0.78 \pm 0.10^{a}$ & $0.17 \pm 0.03^{a}$ \\
\hline
\end{tabular}

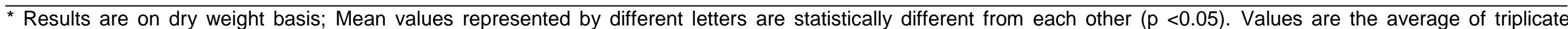

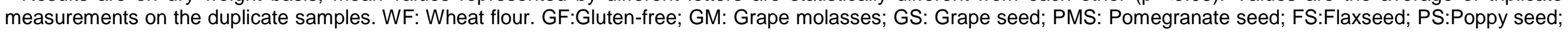
$\mathrm{T}:$ Turmeric 


\section{CONCLUSION}

In this study, the sugar used in the gluten-free cake formulation was replaced with $75 \%$ grape molasses. In addition, the effects of replacing gluten-free cake mix with $5 \%$ grape seed, pomegranate seed, flaxseed, poppy seed and turmeric on the quality of cakes were investigated. In the cake samples, the use of grape molasses together with grape seed, pomegranate seed, flaxseed, poppy seed and turmeric decreased the crust and crumb $L^{*}$ values, while increasing the $a{ }^{*}$ and $b$ * values compared to the gluten-free control samples. In general, the volume index values decreased with the use of additives. All additives significantly increased the ash and crude protein content of the cake samples, while flaxseed and poppy seed also caused significant increases in crude fat content compared to the gluten-free control samples. Grape seed, pomegranate seed, flaxseed, poppy seed and turmeric significantly increased total phenolic content and antioxidant activity of cake samples compared to the gluten-free control sample. Grape seed, pomegranate seed, flaxseed and poppy seed increased $\mathrm{Ca}$, while flaxseed and poppy seeds increased $\mathrm{P}$ and $\mathrm{Mg}$ contents of the cake samples. In addition to grape molasses, all additives in the formulation caused an increase in hardness values compared to the gluten-free control sample. Cakes containing poppy seed and flaxseed scored the highest overall acceptability scores among enriched samples after gluten-free control sample.Further studies could investigate the use of higher levels of flaxseed and poppy seed and lower levels of turmeric in gluten-free cake production.

Funding: This research was funded by The Scientific Research Projects Unit of Karamanoğlu Mehmetbey University, Karaman, Turkey, grant number 10-M-18.

Conflicts of Interest: The authors declare no conflict of interest. The funders had no role in the design of the study; in the collection, analyses, or interpretation of data; in the writing of the manuscript, or in the decision to publish the results.

\section{REFERENCES}

1. Lebwohl B, Ludvigsson JF, Green PH. Celiac disease and non-celiac gluten sensitivity. BMJ 2015 Oct;351:h4347.

2. Fasano A, Catassi C. Current approaches to diagnosis and treatment of celiac disease: an evolving spectrum, Gastroenterology $2001 \mathrm{Feb} ; 120(3): 636-51$.

3. El Khoury D, Balfour-Ducharme S, Joye IJ. A review on the gluten-free diet: technological and nutritional challenges.Nutrients 2018 Oct;10(10):1410.

4. Rubio-Tapia A, Hill ID, Kelly CP,Calderwood AH, Murray JA. American College of Gastroenterology clinical guideline: diagnosis and management of celiac disease.AmJ Gastroenterol. 2013 Apr;108(5):656.

5. Singh P, Arora A, Strand TA, Leffler DA, Catassi C, Green PH, et al. Global prevalence of celiac disease: systematic review and meta-analysis.Clin Gastroenterol Hepatol. 2018 Jun;16.

6. Kulai T, Rashid M. Assessment of nutritional adequacy of packaged gluten-free food products. Can J Diet Pract and Res 2014 Nov;75(4):186-90.

7. Caponio F, Summo C, Clodoveo ML, Pasqualone A. Evaluation of the nutritional quality of the lipid fraction of glutenfree biscuits. Eur Food Res Technol. 2008 Jul;227(1):135-9.

8. Elli L, Ferretti F, Orlando S, Vecchi M, Monguzzi E, Roncoroni L, Schuppan D. Management of celiac disease in daily clinical practice. Eur J Intern Med.2019 Mar; 61:15-24.

9. Demirkesen I, Ozkaya B. Recent strategies for tackling the problems in gluten-free diet and products. Crit Rev Food Sci Nutr. 2020 Sep; 1-27.

10. Jukanti AK, Gaur PM, Gowda CLL, Chibbar RN. Nutritional quality and health benefits of chickpea (Cicer arietinum L.): a review. BrJ Nutr. 2012 Aug;108(S1):S11-S26.

11. Hirdyani H. Nutritional composition of Chickpea (Cicerarietinum-L) and value added products-a review. Indian $\mathrm{J}$ Community Health. 2014 Dec;26Supp 2:102-6.

12. Sharma KD, Karki S, Thakur NS, Attri S. Chemical composition, functional properties and processing of carrot-a review.J Food Sci Technol. 2012 Mar;49(1):22-32.

13. Batu A. [The importance of raisin and pekmez on human health and nutrition]. GIda. 1993 Sep; 18(5):303-7. Turkish.

14. Demirözü B,Sökmen M,Uçak A,Yilmaz H,Gülderen S. Variation of Copper, Iron, and Zinc Levels in Pekmez Products. Bull Environ ContamToxicol. 2002; 69:330-4.

15. Batu A. [Grape, Molasses and Human Health]. GıdaTeknolojileriElektronikDergisi. 2011; 6(2):25-35. Turkish.

16. Kim SY, Jeong SM, Park WP, Nam KC, Ahn DU,Lee SC. Effect of heating conditions of grape seeds on the antioxidant activity of grape seed extracts. FoodChem. 2006 Aug;97(3):472-9.

17. Saito M, Hosoyama H, Ariga T, Kataoka S, Yamaji N. Antiulcer activity of grape seed extract and procyanidins. J Agric Food Chem. 1998Mar;46(4):1460-4. 
18. Thompson LU, Cunnane SC.Flaxseed in human nutrition. AOCS publishing, 2003.

19. Khouryieh H, Aramouni F. Physical and sensory characteristics of cookies prepared with flaxseed flour. J Sci Food Agric. 2012 Mar;92(11):2366-72.

20. Mohagheghi M, Rezaei K, Labbafi M, Ebrahimzadeh Mousavi SM. Pomegranate seed oil as a functional ingredient in beverages. Eur J Lipid Sci Technol. 2011 Feb;113(6):730-6.

21. Bozan B, Temelli F. Extraction of poppy seed oil using supercritical CO2.J Food Sci. 2003 Jul;68(2):422-6.

22. Bozan B, Temelli F. Chemical composition and oxidative stability of flax, safflower and poppy seed and seed oils. Bioresour Technol. 2008 Sep;99(14):6354-9.

23. Chattopadhyay I, Biswas K, Bandyopadhyay U, Banerjee RK. Turmeric and curcumin: Biological actions and medicinal applications. Curr Sci-Bangalore. 2004 Jul;87:44-53.

24. Levent H, Bilgiçli N. Quality evaluation of wheat germ cake prepared with different emulsifiers. J Food Qual. 2013 Sep,36(5):334-41.

25. AACC. Approved Methods of the American Association of Cereal Chemists. 8th edition. St. Paul, MN, Cereals \&Grains Association, 1990.

26. Levent H, Koyuncu M, Bilgiçli N, Adıgüzel E, Dedeoğlu M. Improvement of chemical properties of noodle and pasta using dephytinized cereal brans.LWT-Food Sci Technol. 2020 Jun; 109470.

27. Wronkowska M, Zielińska D, Szawara-Nowak D, Troszyńska A,Soral-Smietana M. Antioxidative and reducing capacity, macroelements content and sensorial properties of buckwheat-enhanced gluten-free bread. Int J Food Sci Technol. 2010 Aug;45(10):1993-2000.

28. Re R, Pellegrini N, Proteggente A, Pannala A, Yang M, Rice-Evans C. Antioxidant activity applying an improved ABTS radical cation decolorization assay. Free Radic Biol Med. 1999 May; 26(9-10):1231-37.

29. Mohamed S, Hamid NA. Effects of ingredients on the characteristics of rice cakes. J Sci Food Agric. 1998 May;76(3):464-8.

30. Akbulut M,Bilgicli N. Effects of different pekmez (fruit molasses) types used as a natural sugar source on the batter rheology and physical properties of cakes. J Food Process Eng. 2010 Mar; 33(2):272-86.

31. Singh JP, Kaur A, Singh N. Development of eggless gluten-free rice muffins utilizing black carrot dietary fibre concentrate and xanthan gum.J Food Sci Technol.2016 Nov;53(2):1269-78.

32. Sudha ML, Begum K, Ramasarma PR. Nutritional characteristics of linseed/flaxseed (Linum usitatissimum) and its application in muffin making. J Texture Stud. 2010 Jul;41(4):563-78.

33. HoyeJrC, Ross CF. Total phenolic content, consumer acceptance, and instrumental analysis of bread made with grape seed flour. J Food Sci. 2011 Sep; 76(7):428-36.

34. Borneo R, Aguirre A and Leon AE. Chia (Salvia hispanica L) gel can be used as egg or oil replacer in cake formulations. J Am Diet Assoc. 2010 Jun; 110:946-9.

35. Bath DE, Shelke K, Hoseney RC. Fat replacers in high ratio cake layer cakes. Cereal Foods World. 1992; 37:495500.

36. Acosta K, Cavender G, Kerr WL. Sensory and physical properties of muffins made with waxy whole wheat flour. J Food Qual. 2011 Oct;34(5):343-51.

37. Gomez M, Oliete B, Rosell CM, Pando V,Fernandez E. Studies on cake quality made of wheat-chickpea flour blends. LWT-Food SciTechnol.2008 Nov; 41(9):1701-9.

38. Koca I, Tekguler B, Yilmaz VA, Hasbay I, Koca AF. The use of grape, pomegranate and rosehip seed flours in Turkish noodle (erişte) production. J Food Process Preservation. 2017 May; 42: e13343.

39. Lim HS, Park SH, Ghafoor K, Hwang SY, Park J. Quality and antioxidant properties of bread containing turmeric (Curcuma longa L.) cultivated in South Korea. Food Chem. 2011 Feb; 124(4):1577-82.

40. Acun Sand Gül H. Effects of grape pomace and grape seed flours on cookie quality. Quality Assurance and Safety of Crops \& Foods. 2014 Mar; 6(1):81-8.

41. Koca AF and Anil M. Effect of flaxseed and wheat flour blends on dough rheology and bread quality. J Sci Food Agric. 2007 Mar; 87(6):1172-5.

42. Rubilar M, Gutiérrez C, Verdugo M, Shene C, Sineiro J. Flaxseed as a source of functional ingredients. J Soil Sci Plant Nutr.2010; 10(3):373-7.

43. Özcan MM and Atalay Ç. Determination of seed and oil properties of some poppy (Papaver somniferum L.) varieties. Grasas Aceites. 2006 Jun; 57(2):169-174.

44. Girard B, Mazza G. 1998. Functional grape and citrus products. In: Mazza G, editor. Functional Foods Biochemical and Processing Aspects.Lancaster, PA: Technomic Publishing; 1998. p.139-91.

45. Yildiz E, Gungor G, Yilmaz H, Gocmen D. Changes in bioaccessibility, phenolic content and antioxidant capacity of novel crackers with turmeric (Curcuma longa L.) and mahaleb (Prunus mahaleb L.) powders. Quality Assurance and Safety of Crops \& Foods. 2019 Jan; 11(2):107-116. 
46. Aksoylu Z, Çağindi Ö and Köse E. Effects of blueberry, grape seed powder and poppy seed incorporation on physicochemical and sensory properties of biscuit. J Food Qual. 2015 Mar; 38(3):164-174.

47. ÖzcanM. Mineral contents of some plants used as condiments in Turkey. Food Chem. 2004; 84(3):437-440.

48. Conforti FD and Davis SF. The effect of soya flour and flaxseed as a partial replacement for bread flour in yeast bread. Int J Food Sci Technol. 2006 Feb; 41:95-101.

49. Menteş Ö, Bakkalbaşşi E and Ercan R. Effect of the use of ground flaxseed on quality and chemical composition of bread. Food Sci Technol Int. 2008 Aug;14(4):299-306.

(c) 2021 by the authors. Submitted for possible open access publication under the terms and conditions of the Creative Commons Attribution (CC BY NC) license (https://creativecommons.org/licenses/by-nc/4.0/). 